\title{
Diamond-bearing kimberlites of northern Europe
}

\author{
V.N. Ustinov ${ }^{1}$, H.O'Brien ${ }^{2}$, L.I. Lukyanova ${ }^{1}$, P.Peltonen ${ }^{2}$ \\ ${ }^{1}$ ALROSA Co. Ltd., St. Petersburg, Russia, \\ ${ }^{2}$ Geological Survey of Finland, Espoo, Finland
}

\section{Structural setting}

The Archean Karelian-Kola megacraton (2.3 mln. $\mathrm{km}^{2}$ ), comprised of the Fennoscandian shield and adjacent Russian platform, contains over 100 kimberlite pipes and associated dykes, sills and stockworks, many of which are diamondiferous.

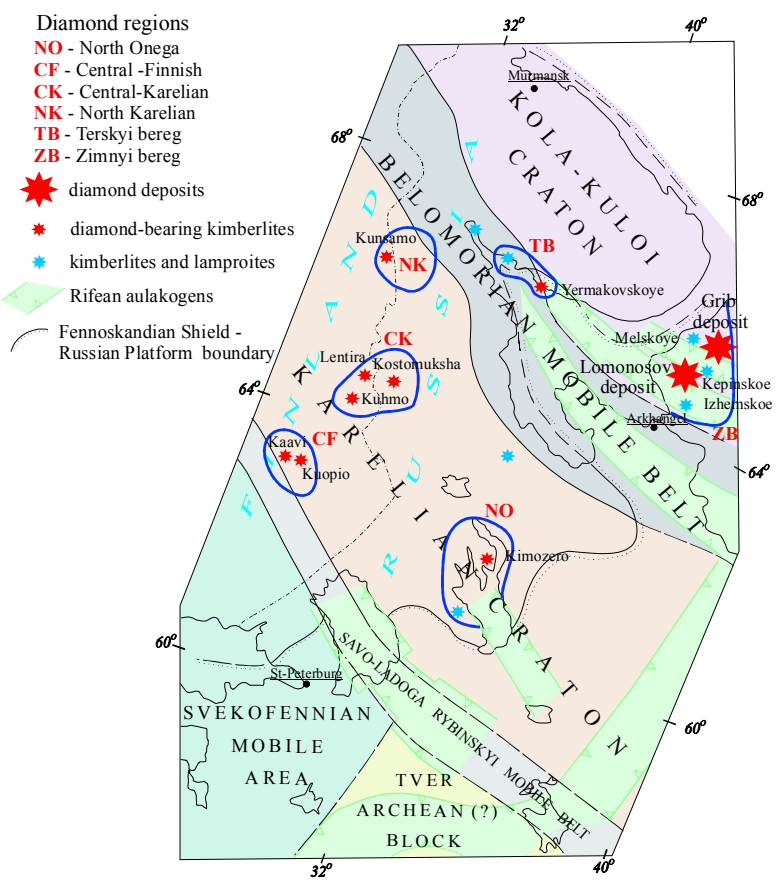

Fig.1 Distribution map of diamond-bearing kimberlites in the Karelian-Kola megacraton.

Within the Karelian-Kola subprovince one can distinguish three diamondiferous areas (Karelian, Belomorian and Kola-Kuloi) corresponding to the cratons with the same names and stabilized by the Archean Belomorian mobile belt. At present six diamondiferous regions have been revealed within these areas: North Onega, Central Finland, Central Karelian, Northern Karelian, Terski Bereg and Zimnyi Bereg, within which kimberlite fields have been distinguished. Occurrences of four epochs of tectonicmagmatic activization have been established: Early Proterozoic (Late Karelian), Middle and Late Riphean (Baikal age), Vendian (Caledonian) and Middle Paleozoic (Hercynian).

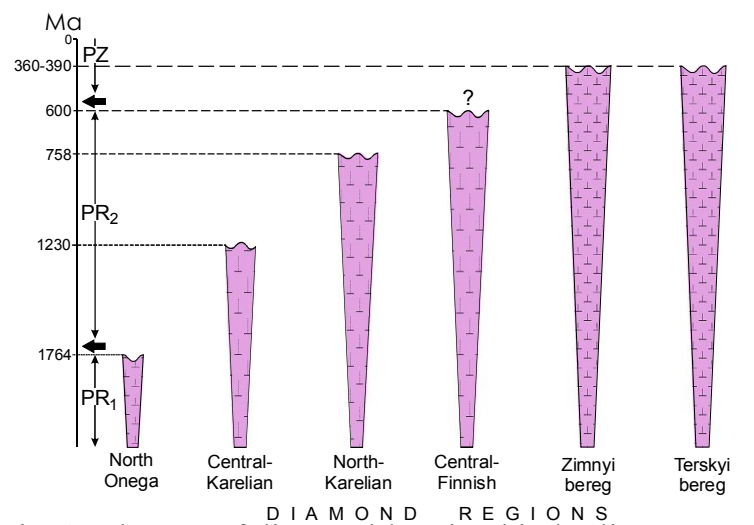

Fig. 2. The age of diamond-bearing kimberlites

\section{Geology and composition of kimberlites}

Early Proterozoic kimberlites $(1764 \pm 125 \mathrm{Ma})$, are present as several distinct fields in the North Onega region, and are among the most ancient diamondbearing rocks in the world. They occur as distinctive saucer shaped $(2 \times 0.8 \mathrm{~km})$ bodies with narrow feeder channels but without well-developed diatremes. This suggests an origin similar to kimberlites like Star (Saskatchewan, Canada), Tokapal (India) and Bakwanga (Central Africa) which were created by feeder vent eruptions forming bedded, pyroclastic deposits.

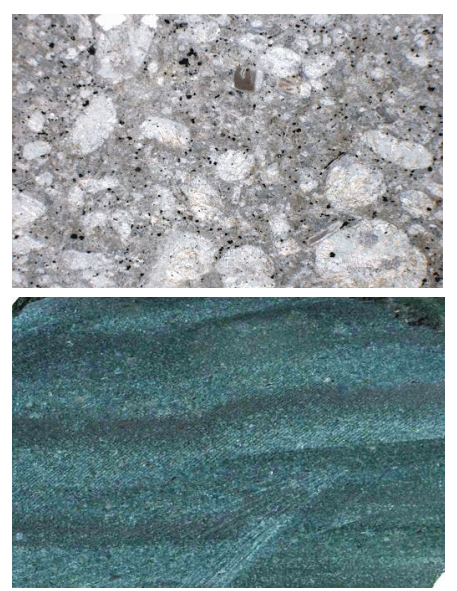

Fig.3. Typical varieties of Early Proterozoic kimberlite rocks of Kimozero: (upper image) amphibolitized kimberlite [field of view 4 x $6.8 \mathrm{~mm}$ ], (lower image) finely bedded kimberlite tuff [field of view $12 \times 20$ $\mathrm{mm}$ ] 
Both Group I and II kimberlites and associated breccias are present in North Onega region. They differ from archetypal, Phanerozoic kimberlites by their very low alkali element and $\mathrm{P}_{2} \mathrm{O}_{5}$ contents, and by an intense late carbonate metasomatism. Kimberlite indicator minerals (KIM) present are chrome-spinels and rare pyropes. Diamonds are colorless resorbed octahedrons, rare octahedron-dodecahedroid forms and macles.

Middle Riphean kimberlites (1200-1231 Ma) are represented by three fields (Kuhmo, Lentiira and Kostomuksha) in the Central Karelian Diamond region and are confined to a near N-S zone of faults. Most of the bodies occur as dikes 0.5 to $4 \mathrm{~m}$ in thickness, extending up to $450 \mathrm{~m}$ in length, and less often as veins or stockworks $(500 \times 500 \mathrm{~m})$.

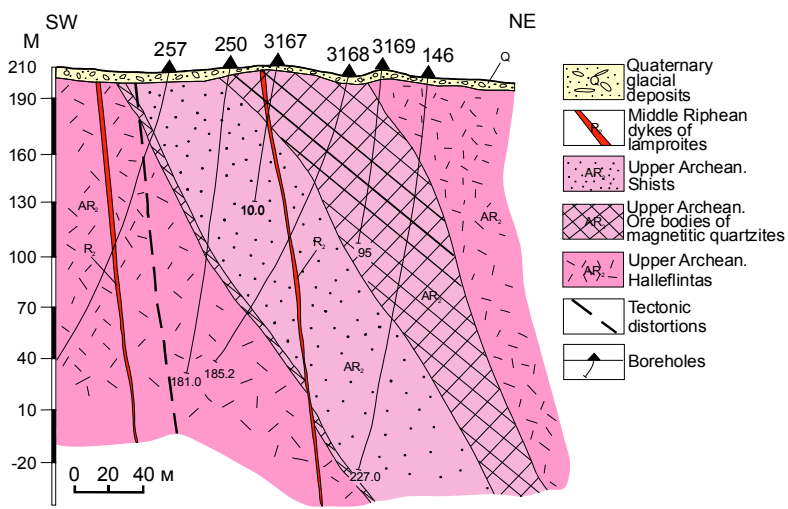

Fig. 4. Geological section of Kostomuksha K2L dykes

Petrological and geochemical features of the kimberlites from the Kostomuksha, Lentiira and Kuhmo fields suggest an affinity with lamproites of Western Australia and partially Sisimiut, Greenland. Mineralogically these phlogopite-rich rocks range from olivine lamproites to Group II kimberlites, K2L (Mahotkin, 1998). KIM are dominantly chrome-spinels with rarer pyropes and microdiamonds $(<1 \mathrm{~mm})$, most of the latter being colorless octahedra.

Late Riphean kimberlites $(758 \pm 6 \mathrm{Ma})$ are represented by seven relatively small ( $<50 \mathrm{~m}$ in diameter) bodies that have been recently discovered within the Northern Karelian diamond region south of Kuusamo (Finland).

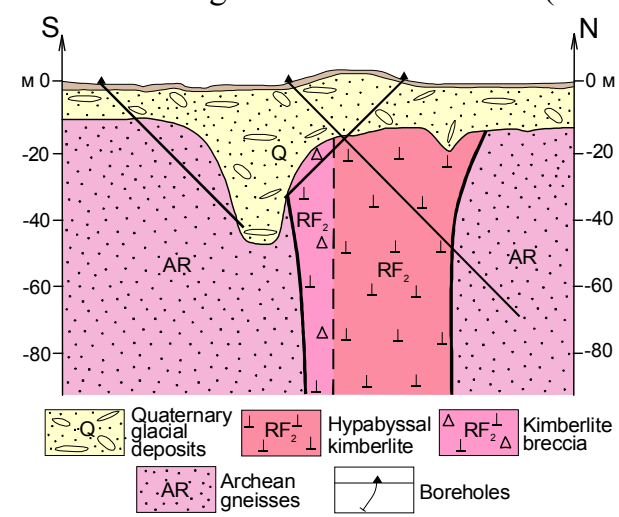

Fig. 5. Geological section of Kuusamo kimberlite Kattaisenvaara (data from Sunrise Diamonds Plc.)
Six of these are hypabyssal intrusions (5 Group I and 1 Group II) have well-developed segregation textures, whereas the seventh has pelletal lapilli and other classical characteristics of diatreme facies kimberlite. KIM are picroilmenites, pyropes and chrome diopsides and so far only microdiamonds have been extracted from these kimberlites.

Vendian kimberlites (600 Ma) of the Kaavi and Kuopio fields range in morphology from hypabyssal dikes 500 x $30 \mathrm{~m}$ in size to nearly circular diatreme pipes up to 4 ha in size (O`Brien, H.E. \& Tyni, 1999).

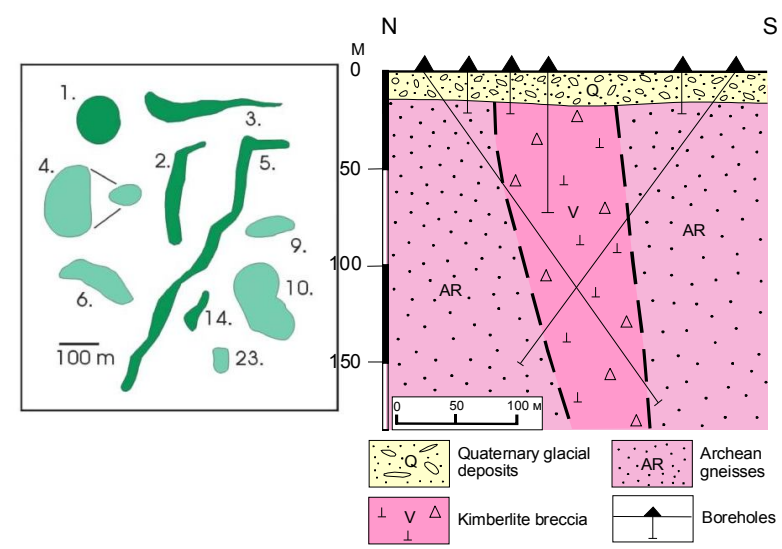

Fig. 6. Kimberlites of Kaavi-Kuopio: morphology of bodies (light green - kimberlite breccia, dark green hypabyssal kimberlite) and geological section of pipe 7 (Karhunen et. al., 2003).

These kimberlites have archetypal Group I mineralogies and chemical compositions. Quantities and compositions of KIM vary among the bodies (O'Brien et. al., 2005; Peltonen et. al., 2002). Many of the pipes are diamondiferous with stones that are mainly octahedral and are similar to crystals from well-known deposits of Siberia. By their petrological features these kimberlites are very similar to many diamondiferous kimberlites of Siberia, to the rocks of Grib pipe and to kimberlites of group I of South Africa. However trace and rare earth elements trends, including high $\mathrm{La} / \mathrm{Yb}$ (80-232), show they differ considerably from Grib pipe $(\mathrm{La} / \mathrm{Yb}$ 56-90) and from the Lomonosov Diamond Deposit (La/Yb 24-31).

Middle Palaeozoic kimberlites (345-385 Ma) occur within the Terskyi Bereg and the Zimnyi Bereg Diamond regions and are mostly diatreme facies, with some crater facies preserved. The Terskyi Bereg low grade pipes are comparatively small (30-40 $\mathrm{m}$ and 130 x 130 m). KIMs include chrome-spinels with $\mathrm{Cr}_{2} \mathrm{O}_{3}>$ $62 \mathrm{wt} \%$, G10 pyropes, and chrome diopsides. By their chemical and mineralogical composition these kimberlites are most similar to Group I kimberlites of the Koidu field in W Africa and Finland. Diamonds are of octahedral shape. 


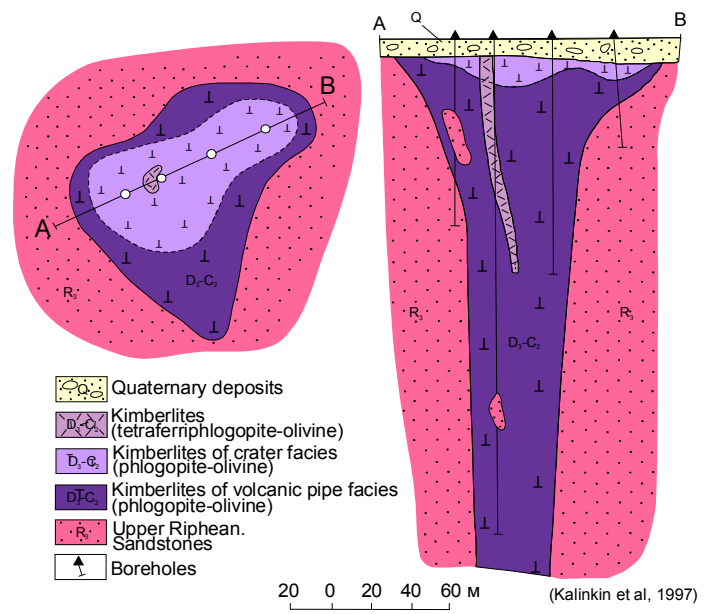

Fig. 7. Geological plan and section of Yermakovsraya7 kimberlite pipe

The Zimnyi Bereg (Winter Coast) diamond area includes the Group II Lomonosov deposit (Zolotitskoye field), and the Group I Grib deposit (Verkhotinskoye field).
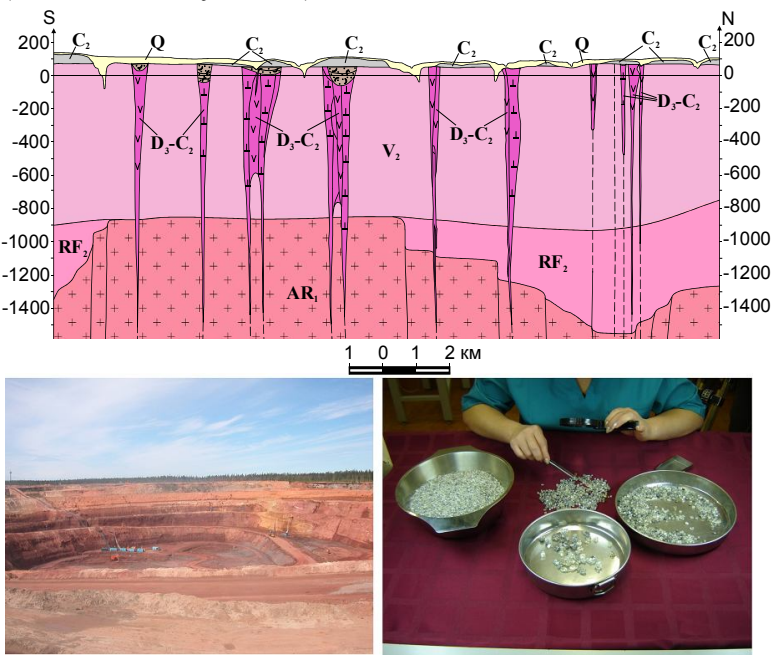

Fig. 8. Geological section, open-pit operations and diamonds from Lomonosov Mine

The Lomonosov deposit that is currently in production has the potential to reach approximately $18 \%$ of the developed diamond reserves of Russia (Piven et.al., 2007). The subsurfaces of all diamond-bearing pipes have widely developed crater facies composed of tuffs and tuff sandstones, which are replaced at depth by xenolith-rich tuffisites and autolithic (lapilli) breccias of diatreme facies. Hypabyssal facies, represented by porphyric kimberlites, composes the root portions of the pipes and intersecting dykes and stocks. Dimensions of the pipes and their morphology vary, with the largest being Pionerskaya pipe $-900 \times 250 \mathrm{~m}$ and Grib pipe $-495 \times 380 \mathrm{~m}$. Characteristics that differ between these two diamond deposits include composition and contents of indicator minerals, crystal morphology of diamonds in large classes, and content of mantle xenoliths. According to their geochemical features Grib pipe kimberlites belong to the Fe-Ti series (Group I kimberlites), while kimberlites of
Zolotitsky field belong to the aluminiferous series (Group II kimberlites). They differ greatly from kimberlites of other provinces of the world by low contents of rare and rare-earth elements but match Koidu and Kaavi-Kuopio kimberlites in terms of $\varepsilon_{\mathrm{Nd}}$ $\varepsilon_{\mathrm{Sr}}$. In terms of $\mathrm{Th} / \mathrm{Pb}$ and $\mathrm{La} / \mathrm{Nb}$, as well as in $\mathrm{Nb}-\mathrm{Zr}$ systematics, these kimberlites occupy an intermediate position between Group I and Group II kimberlites of South Africa (Ustinov, 2005).

\section{Conclusions}

Detailed research on the diamondiferous kimberlites of the Karelian-Kola megacraton shows a number of specific features of these rocks and the history of their evolution: 1. A spectrum of kimberlites from Group I, II and lamproite-kimberlitic rocks (K2L) comprise different types of bodies including dykes, sills, stockworks, pipes of various shapes and feeders with surrounding pyroclastic deposits. 2. A wide age range (more than $1400 \mathrm{Ma}$ ) of kimberlitic magmatism. 3 . Considerable range (low, medium and high) in the erosional level of kimberlite bodies depending more on the structural setting of the rocks than on the age of formation. 4. Extensive alteration (carbonitization, magnetitization and amphibolitization) of Proterozoic kimberlites. 5. Octahedral diamonds from Proterozoic primary sources differ from stones from Phanerozoic rocks by small sizes and grades. 6. Diamond crystals of I-VII varieties (by Orlov) are typical for known Phanerozoic primary sources. 7 . The dominant size of diamond indicator minerals is $-1 \mathrm{~mm}$. 8. A large contrast in kimberlite composition, KIM composition and content and diamond grades in bodies that are close neighbors.

\section{References}

O'Brien, H.E., Tyni, M., 1999. Mineralogy and Geochemistry of kimberlites and related rocks from Finland. In: Gurney, J.J. et al. (eds.), Proceedings of the 7th International Kimberlite Conference, vol. 2, p. 625-636.

O’Brien, H., Peltonen, P., Vartiainen, H., 2005. Kimberlites, carbonatites, and alkaline rocks. In: Lehtinen, M., Nurmi, P.A. \& Rämö, O.T. (eds.). Precambrian of Finland - a Key to the Evolution of the Fennoscandian Shield. Elsevier, Amsterdam, p. 616-646.

Karhunen, J. , Lehtonen, M., Marmo, J., O’Brien, H., 2003. The Lahtojoki diamond prospect, Eastern Finland. Geological Survey of Finland. Espoo, Finland, 36 p.

Mahotkin, I.L., 1998. Petrology of Group 2 KimberliteOlivine lamproite (K2L) series from the Kostomuksha area, Karelia area, N.W. Russia. 7th Int. Kimberlite Conf. Ext. Abstracts, p. 529-531.

Peltonen, P., Kinnunen, K. A., Huhma, H. 2002. Petrology of two diamondiferous eclogite xenoliths from the Lahtojoki kimberlite pipe, eastern Finland. Lithos 63, p. 151-164.

Piven, G.F., Abramov, N.P., Ustinov, V.N., 2007 Mining Development of Lomonosov Diamond Deposit, Russia. $6^{\text {th }}$ Fennoscandian Exploration and Mining». Rovaniemi-Finland, p..31-34

Ustinov, V.N., Diamond exploration of ALROSA in European Russia. Presentation at PDAC, Toronto Canada. 